\title{
Evaluation of Extraction Methods for Progesterone Metabolite Determination in Buffalo Feces by Immunoassay
}

\author{
D. Gupta ${ }^{1}$, G. Singh ${ }^{1 *}$, G. Kashyap ${ }^{2}$, M. C. Pathak ${ }^{1}$, P. Patel ${ }^{1}$, \\ M. Sarkar ${ }^{1}$, V. S. Chouhan ${ }^{1}$ and M. R. Verma $^{3}$ \\ ${ }^{1}$ Division of Physiology and Climatology, ${ }^{2}$ Division of Pathology, ${ }^{3}$ Division of Livestock \\ Economics, Statistics and Information Technology, IVRI, Bareilly, UP, India \\ *Corresponding author
}

Ke y w o r d s
$\begin{aligned} & \text { Extraction, Feces, } \\ & \text { Progesterone, } \\ & \text { Metabolite }\end{aligned}$
Article Info
$\begin{aligned} & \text { Accepted: } \\ & \text { 10 September } 2020 \\ & \text { Available Online: } \\ & 10 \text { October } 2020\end{aligned}$

\section{A B S T R A C T}

The present study was planned to develop the best fecal extraction method for progesterone metabolite assay which is based on the concentration of fecal progesterone

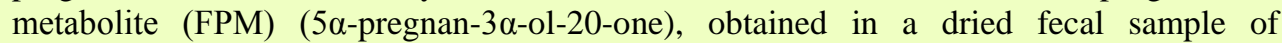
buffaloes. Four clinically healthy female buffaloes of the same age group 4 to 7 years were used for the collection of fecal samples maintained under isomanagerial conditions with an intensive system at the LPM Section of the IVRI institute. The extraction of FPM (5 5 pregnan-3 $\alpha$-ol-20-one) was done by various methods using organic solvents like methanol, diethyl ether, ethanol, and $90 \%$ methanol and found that extraction with $90 \%$ methanol the concentration of FPM ( $5 \alpha$-pregnan-3 $\alpha$-ol-20-one) $(231.98 \mathrm{ng} / \mathrm{g}$ ), is comparatively higher than other methods and best for a dried fecal sample of buffaloes. In conclusion, the above results suggest that FPM (5 $\alpha$-pregnan-3 $\alpha$-ol-20-one) value using $90 \%$ methanol as a solvent in the dried fecal sample assay having high value as compared to other solvents extraction methods like methanol, absolute ethanol, and diethyl ether, and we reported best for a dried fecal sample of buffaloes and preserved for further estimation.

\section{Introduction}

India possesses a rapidly increasing animal husbandry sector and moves to attain selfsufficiency in the production of livestock products (Dhama et al., 2014). Animal husbandry is a major contributor to the Indian economy and overall contribution is $28-32 \%$ in agricultural GDP and 4 to $6 \%$ of the national GDP. India possesses the largest buffalo population (109.85 million) in the world (Chand et al., 2015, 20th Livestock census, 2019). The use of steroid hormone concentration measured in feces as a noninvasive method for detecting reproductive status has been used in various research fields such as wildlife endocrinology, animal welfare, ecology, and reproduction (Dantzer et al., 2013; Schwarzenberger and Brown, 2013). Metabolism and excretion of steroids differ widely between species and even between sexes (Touma et al., 2003; Palme et al., 2005) and a mixture of several metabolites with different structures and 
polarities. Such non-invasive methods therefore need to be extensively validated for each species (Touma and Palme, 2005). Proper extraction technique is necessary to choose for the steroid metabolites present in the faecal matrix are of varying polarity and composition. Studies of fecal steroid hormones were first conducted mainly on their metabolism and excretion (Adlecreutz et al., 1979), further studies were done regarding the puberty, estrous cycle, pregnancy, abortion, reproductive behavior, seasonality, and the monitoring of treatment therapies in the zoo and domestic animals (Schwarzenberger et al., 1996). The presence of quantified amounts of reproductive steroids was present in cattle feces (Desaulniers et al., 1989; Larter et al., 1994; Isobe et al., 2005) and other animals (Shaw et al., 1995).

The steroid hormone metabolite quantified in faeces, commonly used in wildlife studies, as a non-invasive, non-stressing, economical, and animal-saving technique that permits longitudinal studies by allowing frequent sampling of the same individual (Brown et al., 1994; Graham et al., 1995). Thus, developing enzyme immunoassays (EIAs) against Progesterone metabolites would be more accurate and reliable for non-invasive reproductive monitoring method using fecal samples (Brown et al., 1994; Umapathy et al., 2013; Mithileshwari et al., 2016; Budithi et al., 2016, Marozzi et al., 2019, Amaral et al., 2019). In various studies, the organic solvent was used by the various workers for the extraction of steroid hormone metabolites from feces. Steroids are commonly extracted from feces using ethanol in Goat (Capezzuto et al., 2008), Felid (Brown et al, 1994), Asiatic lion (Umapathy et al., 2007), Scimitar-horned oryx (Morrow and Monfort, 1998), Baboons (Waser et al., 1993). Methanol was used for extraction of fecal steroids in Felid (Graham et al., 1995), Exotic cat (Putranto et al., 2006), White rhinoceros
(Schwarzenberger and Walzer, 1995), Black rhinoceros (Schwarzenberger et al., 1993a), Cattle (Schwarzenberger et a. 1996a, 1996b, 1996c; Isobe et al., 2005), Ruminant (Kornmatitsuk et al., 2007; Larter et al., 1994), Buffalo (Hattab et al., 2000; Palme et al., 1997; Arunji, 2008; Ashok, 2011), Bengal tiger (Putranto et al., 2006), Goat (Airin et al., 2020). The fecal samples were extracted with diethyl ether in Cattle (Mostl et al., 1984; Hirata and Mori, 1995), Caribou (Desaulnier et al., 1989; Messier et al., 1990), Sow (Choi et al., 1987), Giant ant-eater (Mostl et al., 1984). Progesterone metabolites in feces were extracted using phosphate buffer solution by Hulten et al., (1995) in gilts and by Petroleum ether in Rabbit by Komdorfer et al., (1998). The present study investigated the best fecal extraction method for progesterone metabolite assay based on the concentration of fecal progesterone metabolite ( $5 \alpha$-pregnan-3 $\alpha$-ol20-one) obtained in a dried fecal sample of buffaloes.

\section{Materials and Methods}

The present study was conducted at the Livestock Production Management (LPM) farm and the facilities of Physiology and Climatology Division and Nuclear Research Laboratory (NRL), ICAR- Indian Veterinary Research Institute, Bareilly (UP) were utilized.

Four clinically healthy female buffaloes of the same age group 4 to 7 years were used for the collection of fecal samples maintained at the LPM Section of the institute and were maintained under isomanagerial conditions with an intensive system and housed in a well-ventilated brick cemented house with a non-slippery floor and offered adlibitum access to standard ration having green and dry fodder along with concentrate and good quality drinking water. 


\section{Screening of suitable extraction method}

Approximately $10-15 \mathrm{~g}$ fecal samples were collected directly from the rectum in interlocking polythene bags and kept in a hot air oven at $40-50^{\circ} \mathrm{C}$ till the sample becomes completely dry. The dry samples were further grounded to powder by using pestle and mortar and stored at $-20^{\circ} \mathrm{C}$ until analysis. The samples were further processed for the extraction of $\mathrm{P} 4$ metabolites by using organic solvents like methanol, diethyl ether, ethanol, and $90 \%$ methanol to select the best among four methods as below. The extraction of steroids in the fecal samples was carried out according to modified methods described by Desaulniers et al., (1989); Thompson et al., (1998); Isobe et al., (2005); Arunji, (2008) and Ashok, (2011).

In Method 1 absolute methanol was used. In this $0.3 \mathrm{~g}$, fecal sample and $5 \mathrm{ml}$ methanol were taken in a tarson centrifuged tube and vortexed in the spinx vortex mixture for 10 minutes than Centrifuged in non-refrigerated Centrifuge (Remi, India) at $3000 \mathrm{rpm}$ for 10 minutes. After that supernatant collected in collecting vial and kept in hot air oven (Yorco instrument, Bombay) overnight for drying at $40-50^{\circ}$ C. After drying reconstituted in the appropriate buffer (ELISA buffer- PBS, $0.01 \%$ Thiomersal, $0.1 \%$ BSA, pH-7.2) and vortexed for 1 minute and preserved in the deep freezer until assay. In the other methods, despite methanol, absolute ethanol, diethyl ether, and $90 \%$ methanol were used remaining procedure same as the methanol method. Method 4 using 90\% methanol with dry samples selected as the best method for progesterone metabolite assay based on the concentration of metabolite obtained. Hence, all the samples were extracted in $90 \%$ methanol and preserved for further estimation. The extraction efficiency of fecal steroids was estimated by adding a known amount of $3 \mathrm{H}$-labeled progesterone tracer in fecal samples before extraction. The extraction efficiency was calculated as a percentage of the amount of labeled hormones observed relative to the amount expected. The extraction efficiency was found to be $85 \%$. The samples were diluted 1:160 with ELISA buffer for progesterone metabolite assay.

\section{Immunoassay procedure}

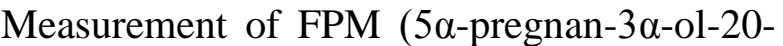
one) was performed by Immunoassay procedures which were carried out according to standard methods. The Inter-assay and Intra-assay coefficient of variation of Immunoassay was $<6.5 \%, \quad<9.0 \%$, respectively. The recovery of spiked $5 \alpha$ pregnan-3 $\alpha$-ol-20-one was found to be $95 \%$ in fecal extracts analyzed by ELISA. The $5 \alpha-$ pregnan-3 $\alpha$-ol-20-one assay sensitivity was $0.1 \mathrm{ng} / \mathrm{ml}$.

\section{Statistical Analysis}

The data generated in the present study were analyzed using JMP 9.0 software.

\section{Results and Discussion}

The present study was designed to develop the best extraction method for progesterone metabolite assay based on the concentration

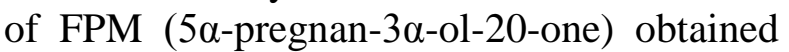
in a dried fecal sample of buffaloes. After fecal samples dried on $40-50^{\circ} \mathrm{C}$ in hot air oven by using variou organic solvents like methanol, diethyl ether, ethanol, and 90\% methanol. After extraction samples were analyzed using ELISA and the values are presented in table 1 . The average values of all the four samples extracted by the ethanol $(80.11 \mathrm{ng} / \mathrm{g})$, diethyl ether $(95.62 \mathrm{ng} / \mathrm{g})$, methanol $(191.08 \mathrm{ng} / \mathrm{g})$, and $90 \%$ methanol $(231.98 \mathrm{ng} / \mathrm{g})$ in a dried fecal sample. Based on the concentration of fecal progesterone metabolite, it was found that the extraction of 
a fecal sample with $90 \%$ methanol is comparatively higher than other methods.

In the previous studies extraction of fecal progesterone was performed using methanol as solvent was reported by various authors in different species such as Schwarzenberger et al., (1993a) in Black rhinoceros, (1996b) in cows and Schwarzenberger and Walzer, 1995 in white rhinoceros, Graham et al., (1995) in felids, Putranto et al., (2006) in exotic cats, Ghosal et al., (2010, 2012) in Asian elephants, Yujiang et al., (2019) in porpoise. In Ruminant species such as Larter et al.,
(1994), Kornmatisuk et al., (2007), Isobe et al., (2005) in cows, Hattab et al., (2000), Arunji, (2008), Ashok, (2011) in buffaloes and Jack et al., (2012) in goats. Extraction of fecal progesterone using $90 \%$ methanol in black rhinoceros by Edwards et al., (2014), Chelonians by Umapathy et al., (2015) and by $80 \%$ methanol in cattle by Palme et al., (1997), goats by Airin et al., (2020), ewes by Amaral et al., (2019), Tsushima leopard cat by Adachi et al., (2010) as well as in Asian Elephants by Kumar et al., $(2014,2019)$ and guanacos by Marozzi et al., (2019).

Table.1 Faecal progesterone metabolite ( $5 \alpha$-pregnan-3 $\alpha$-ol-20-one) concentration (ng/g) (Mean) in buffaloes

\begin{tabular}{|c|c|c|c|c|c|}
\hline \multirow{2}{*}{ Sample } & Animal No. & \multicolumn{4}{|c|}{ Solvents used } \\
\cline { 3 - 6 } & & Ethanol & Diethyl Ether & Methanol & 90\% Methanol \\
\hline \multirow{2}{*}{ Dry } & 114 & 159.64 & 50.40 & 282.00 & 322.81 \\
\cline { 2 - 6 } & 350 & 52.99 & 67.27 & 222.71 & 273.77 \\
\cline { 2 - 6 } & 1038 & 46.50 & 121.49 & 148.66 & 173.58 \\
\hline \multirow{2}{*}{ Average } & 61.31 & 143.34 & 110.95 & 157.78 \\
\hline \multicolumn{2}{|c|}{ Averyyyyy} \\
\cline { 2 - 6 } & 1091 & 80.11 & 95.62 & 191.08 & $\mathbf{2 3 1 . 9 8}$ \\
\hline
\end{tabular}

This study showed a high FPM ( $5 \alpha$-pregnan$3 \alpha$-ol-20-one) value using $90 \%$ methanol as a solvent in the dried fecal sample. There is an average value of $231.98 \mathrm{ng} / \mathrm{g}$ for FPM ( $5 \alpha-$ pregnan-3 $\alpha$-ol-20-one) which is higher than other methods. Our studies show the better application of $90 \%$ methanol as a solvent in dry fecal samples which is similar to previous reports by Edwards et al., (2014) in black rhinoceros and Umapathy et al., (2015) in Chelonians. So method using $90 \%$ methanol as a solvent is best and increase accuracy for determination of FPM ( $5 \alpha$-pregnan-3 $\alpha$-ol-20one) in a dried fecal sample of buffaloes for different investigation.

In Conclusion, the above results suggest that fecal progesterone metabolite (5 $\alpha$-pregnan$3 \alpha$-ol-20-one) value using $90 \%$ methanol as a solvent in the dried fecal sample assay having high value as compared to other solvents extraction methods like methanol, absolute ethanol, and diethyl ether, and we reported best for a dried fecal sample of buffaloes and preserved for further estimation.

\section{Acknowledgments}

The authors are grateful to the Director, ICAR-IVRI, Bareilly, UP (India) for providing the necessary facilities to accomplish this research.

\section{Disclosure statement}

No potential conflict of interest was reported by the authors. 


\section{Abbreviation}

Fecal progesterone metabolite (FPM), Indian Veterinary Research Institute (IVRI), Livestock Production Management (LPM), Nuclear Research Laboratory (NRL), Artificial Insemination (AI), ELISA (Enzyme-Linked Immunosorbent Assay)

\section{References}

Adachi, I., Kusuda, S., Nagao, E., Taira, Y., Asano, M., Tsubota, T. and Doi, O. 2010. Fecal steroid metabolites and reproductive monitoring in a female Tsushima leopard cat (Prionailurus bengalensis euptilurus). Theriogenology, 74(8): 1499-1503.

Adlercreutz, H., Martin, F., Javenpan, P. and Fotsis, T. 1979. Steroid absorption and enterohepatic recycling. Contraception, 20: 201-223.

Airin, C. M., Hana, A., Sarmin, S. and Astuti, P. 2020. Fecal Cortisol and Progesterone Concentrations in Post Partus of Etawah Crossbreed Goat. In E3S Web of Conferences (Vol. 151, p. 01031). EDP Sciences.

Amaral, R. D. S., Ferreira, M. F., Nunes, B. L. M., Gomes, L. A. and Melo, A. N. D. 2019. Monitoring of progesterone and estrone fecal metabolites throughout gestation in ewes. Ciência Animal Brasileira, 20.

Arunji, J.T.K. 2008. Non-invasive monitoring of buffalo estrous cycle. M. V. Sc. Thesis, IVRI, Izatnagar.

Ashok, k. 2011. Faecal steroids as a tool of pregnancy diagnosis in buffalo. $\mathrm{M}$. V. Sc. Thesis, IVRI, Izatnagar.

Brown, J.L., Wasser, S.K., Wildt, D.E. and Graham. L.H. 1994. Comparative aspects of steroid hormone metabolism and ovarian activity in felids, measured non invasively in faeces. Biol. Reprod. 51: 776-786.
Budithi, N.R.B., Kumar, V., Yalla, S.K., Rai, U. and Umapathy, G. 2016. Noninvasive monitoring of reproductive and stress hormones in the endangered red panda (Ailurus fulgens fulgens). Animal reproduction science, 172: 173-181.

Capezzuto, A., Chelini, M.O.M., Felippe, E.C.G. and Oliveira, C.A. 2008. Correlation between serum and fecal concentrations of reproductive steroids throughout gestation in goats. Anim. Reprod. Sci. 103: 78-86.

Chand, M., Evans, J., Swift, R.I., Tekkis, P.P., West, N.P., Stamp, G. and Brown, G. 2015. The prognostic significance of postchemoradiotherapy highresolution MRI and histopathology detected extramural venous invasion in rectal cancer. Annuals of surgery, 261(3): 473-479.

Choi, H.S., Kiesenhofer, E., Gantner, H., Hois, J. and Bamberg, E. 1987. Pregnancy diagnosis in sows by estimation of oestrogens in blood, urine and faeces. Anim. Reprod. Sci. 15: 209-216.

Dantzer, B., Newman, A.E.M., Boonstra, R., Palme, R., Boutin, S., HumphrieS, M.M. and Mcadam, A.G. 2013. Density triggers maternal hormones that increase adaptive offspring growth in a wild mammal. Science, 340: 1215-1217.

Desaulniers, D.M., Goff, A.K., Betteridge, K.J., Rowell, J.E. and Flood, P.F. 1989. Reproductive hormone concentrations in faeces during the estrous cycle and pregnancy in cattle (Bos taurus) and musk oxen (Ovibos moschatus). Can. J. Zool. 67: 11481154.

Dhama, K., Karthik, K., Chakraborty, S., Tiwari, R., Kapoor, S., Kumar, A. and Thomas, P. 2014. Loop-mediated isothermal amplification of DNA 
(LAMP): a new diagnostic tool lights the world of diagnosis of animal and human pathogens: a review. Pakistan journal of biological sciences, 17(2): 151-166.

Edwards, D. P., Tobias, J. A., Sheil, D., Meijaard, E. and Laurance, W. F. 2014. Maintaining ecosystem function and services in logged tropical forests. Trends in ecology \& evolution, 29(9): 511-520.

Ghosal, R. A. T. N. A., Sukumar, R. and Seshagiri, P. B. 2010. Prediction of estrus cyclicity in Asian elephants (Elephas maximus) through estimation of fecal progesterone metabolite: development of an enzyme-linked immuno-sorbent assay. Theriogenology, 73(8): 1051-1060.

Ghosal, R., Kalaivanan, N., Sukumar, R. and Seshagiri, P. B. 2012. Assessment of estrus cyclicity in the Asian elephant (Elephas maximus) by measurement of fecal progesterone metabolite $5 \alpha-\mathrm{P}$ $3 \mathrm{OH}$, using a non-invasive assay. General and Comparative Endocrinology, 175(1): 100-108.

Graham, L.H., Goodrowe, K.L., Raeside, J.I. and Lipttap, R.M. 1995. Non-invasive monitoring of ovarian function, in several felid species by measurement of faecal estradiol-17 $\beta$ and progestins. Zoo BioI. 14: 223-237.

Hattab, S.A., Kadom, A.K., Palme, R. and Banberg, E. 2000. Effect of Crestar on estrus synchronistion and the relationship between faecal and plasma concentration of progesterones in buffalo cows. Theriogenology, 54: 1007-1017.

Hirata, S. and Mori, Y. 1995. Monitoring reproductive status by faecal progesterone analysis in ruminants. $\mathrm{J}$. Vet. Med. Sci. 57: 845-850.

Hulten, F., Zhang, B.R., Frosberg, M. and Dalin, A.M. 1995. Applying a progesterone assay to faecal samples collected from sows during the estrous cycle. Reprod. Dom. Anim. 30: 101106.

Isobe, N., Akita, M., Nakao, T., Yamashiro, H. and Kubota, H. 2005. Pregnancy diagnosis based on the faecal progesterone concentration in beef and dairy heifers and beef cows. Anim Reprod. Sci. 90: 211-218.

Jack, A. M. M., C-C. Chang, H-I. Peh. and Chan, J. P-W. 2012. Fecal progesterone for monitoring reproductive status in dairy goats. Turkish Journal of Veterinary and Animal Sciences, 36: 566-572.

Komdorfer, C.M., Meireller, C.F., Bueno, C. and Abdalla, A.L. 1998. Evaluation of extraction methods for progestrone determination in rabbit (Oryctolagun cuniculas) faeces by radio immuno assay. Braz. J. vet Res. Anim, Sci. 35(3): 115-119.

Kornmatitsuk, B., Thitaram, C. and Kornmatitsuk, S. 2007. Measurement of faecal Progestrone Metabolites and its application for Early Screening of Open Cows Post-insemination. Reprod. Dom. Anim. 42(3): 238-242.

Kumar, V., Pradheeps, M., Kokkiligadda, A., Niyogi, R. and Umapathy, G. 2019. Non-invasive assessment of physiological stress in captive Asian elephants. Animals, 9(8): 553.

Kumar, V., Reddy, V. P., Kokkiligadda, A., Shivaji, S. and Umapathy, G. 2014. Non-invasive assessment of reproductive status and stress in captive Asian elephants in three south Indian zoos. General and comparative endocrinology, 201: 37-44.

Larter, N.C., Rajamahendran, R. and Sivakumaran, $\quad$ K. 1994. Immunoreactive faecal progestins as indicators of reproductive status. Vet. Rec. 134: 474-475. 
Livestock Census 20 ${ }^{\text {th }}$ 2019. Ministry Of Agriculture Department Of Animal Husbandry,Dairying And Fisheries Krishi Bhawan, New Delhi.

Marozzi, A., Cantarelli, V. I., Gomez, F. M., Panebianco, A., Leggieri, L. R., Gregorio, P. and Carmanchahi, P. D. 2020. A predictive model to diagnose pregnancy in guanacos (Lama guanicoe) using non-invasive methods. Canadian Journal of Zoology, 98(1): 13-20.

Messier, F., Desaulniers, D.M., Goff, A.K., Nault, R., Patenaude, R. and Crete, M. 1990. Caribou pregnancy diagnosis from immunoreactive progestins and estrogens excreted in feces. The Journal of wildlife management, 279283.

Mithileshwari, C., Srivastava, T., Kumar, V., Kumar, A. and Umapathy, G. 2016. Non-invasive assessment of fecal progestagens and pregnancy detection in Himalayan musk deer (Moschus chrysogaster). Theriogenology, 85(2): 216-223.

Morrow, C.J. and Monfort, S.L. 1998. Ovarian activity in the scimitar-horned oryx (Oryx dammah) determined by faecal steroid analysis. Anim. Reprod. Sci. 53: 191-207.

Mostl, E., Choi, H.S., Wurm, W., Ismail, M.N. and Bamberg, E. 1984. Pregnancy diagnosis in cows and heifers by determination of oestradiol$17 \beta$ in faeces. Br. Vet. J. 140: 287291.

Palme, R. 2005. Measuring Faecal steroids : guidelines for practical application. Ann. N.Y. Acad. Sci. 1046: 75-80.

Palme, R., Mostl, E., Brem, G., Schellander, K. and Bamberg, E. 1997. Faecal metabolites of infused $\mathrm{C}^{14}$ progesterone in domestic livestock. Reproduction in Domestic Animal. 32: 199-206.
Putranto, H.D., Kusuda, S., Mori, Y., Inagaki, K. and Doi, O. 2006. Assessment of ovarian cycle by faecal progesterone and estradiol-17P in exotic cat. Chulalongkorn Uni. Fac. Vet. Sc., Bangkok, Thailand, 26-29.

Schwarzenberger, F. and Brown, J.L. 2013. Hormone monitoring: An important tool for the breeding management of wildlife species. Wien Tierärztl Monat - Vet Med Austria, 100: 209-225.

Schwarzenberger, F. and Walzer, C. 1995. Estrous cycle induction in a white rhinoceros (Ceratotherium simum simum) monitored by faecal progestagen analysis. Verh. ber. Erkrg. Zootiere. 37:79-83.

Schwarzenberger, F., E. Mostl, R. Palme and E. Bamberg 1996. Fecal steroid analysis for non-invasive monitoring of reproductive status in farm, wild and zoo animals. Anim. Reprod. Sci. 42: 515 - 526.

Schwarzenberger, F., Francke, R. and Göltenbothm, R. 1993a. Concentrations of faecal immunoreactive progestagen metabolites during the estrous cycle and pregnancy in the black rhinoceros (Diceros bicornis michaeli). J. Reprod. Fertil. 98: 283-291.

Schwarzenberger, F., Mostl, E., Palme, R. and Bamberg, E. 1996a. Faecal steroid analysis for non-invasive monitoring of reproductive status in farm, wild and zoo animals. Anim. Reprod. Sci. 42: 515-526.

Schwarzenberger, F., Son, C.H., Pretting, R. and Arbeiter, K. 1996b. Use of groupspecific antibodies to detect faecal progesterone metabolites during the estrous cycle of cows. Theriogenology. 46: 23-32.

Schwarzenberger, F., Tomasova, K., Holeckova, D., Matern, B. and Mostl, E. 1996c. Measurement of fecal 
steroids in the black rhinoceros (Diceros bicornis) using groupspecific enzyme-immunoassays for 20-oxo-pregnanes. Zoo Biol. 15: 159171.

Shaw, H.J., Green, D.I., Sainsbury, A.W. and Holt, W.V. 1995. Monitoring ovarian function in scimitar-horned oryx (Oryx dammah) by measurement of faecal $20 \alpha$ progestagen metabolites. Zoo Biol. 14: 239-250.

Thompson, K.V., Mashburn, K.L. and Monfort, S.L. 1998. Characterization of estrous cyclicity in the sable antelope through faecal progestagen monitoring. Gen. Comp. Endocrin. 112: 129-137.

Touma, C. and Palme, R. 2005. Measuring fecal glucocorticoid metabolites in mammals and birds. The importance of validation. Ann NY Acad Sci. 1046: 54-74.

Touma, C., Sachser, N., Möstl, E. and Palme, R. 2003. Effect of sex and time of day on metabolism and excretion of corticosterone in urine and feces of mice. Gen Comp Endocrinol. 130: $267-278$

Umapathy, G., Deepak, V., Kumar, V., Chandrasekhar, M. and Vasudevan, $\mathrm{K}$. 2015. Endocrine profiling of endangered tropical chelonians using noninvasive fecal steroid analyses. Chelonian Conservation and Biology, 14(1): 108-115.

Umapathy, G., Kumar, V., Wasimuddin., Kabra, M. and Shivaji, S. 2013. Detection of pregnancy and fertility status in big cats using an enzyme immunoassay based on $5 \alpha$-pregnane$3 \alpha$-ol-20-one. Gen Comp Endocrinol. 180: 33-38.

Umapathy, G., Sontakke, S.D., Srinivasu, K., Kiran, T., Kholkute, S.D. and Shivaji, S. 2007. Estrus behavior and faecal steroid profiles in the Asiatic lion (Panthera leo persica) during natural and gonadotropin-induced estrus. Anim. Reprod. Sci. 101(3-4): 313-325.

Wasser, S.K., Thomas, R., Nair, P.P., Guidry, C., Southers, J., Lucas, J., Wildt, D.E. and Monfort. S.L. 1993. Effect of dietary fibre on faecal steroid measurements in baboons (Papio cynocephalus cynocephalus). J. Reprod. Fert. 97: 569-574.

Yujiang, H., Nabi, G., Deng, X. J. and Ding, W. 2019. Non-invasive fecal steroid measurements for monitoring the reproductive status of a critically endangered Yangtze finless porpoises (Neophocaena asiaeorientalis asiaeorientalis). Frontiers in endocrinology, 10: 606.

\section{How to cite this article:}

Gupta, D., G. Singh, G. Kashyap, M. C. Pathak, P. Patel, M. Sarkar, V. S. Chouhan and Verma, M. R. 2020. Evaluation of Extraction Methods for Progesterone Metabolite Determination in Buffalo Feces by Immunoassay. Int.J.Curr.Microbiol.App.Sci. 9(10): 943-950. doi: https://doi.org/10.20546/ijcmas.2020.910.113 